\title{
THE EVALUATION OF THE EXHAUST EMISSION LEVEL OF COMBAT VEHICLES UNDER DIFFICULT TERRAIN CONDITIONS ON THE EXEMPLE ARMORED COMBAT VEHICLE "ROSOMAK" - PART I
}

\author{
OCENA WŁAŚCIWOŚCI EKOLOGICZNYCH \\ POJAZDÓW BOJOWYCH \\ W WARUNKACH POLIGONOWYCH \\ NA PRZYKLADZIE KOLOWEGO TRANSPORTERA \\ OPANCERZONEGO KTO „ROSOMAK” - CZEĆĆ I
}

\author{
Jacek Ryczyński, Maciej Szukalski
}

Military University of Land Forces, Faculty of Management Akademia Wojsk Lądowych, Wydział Zarządzania

\begin{abstract}
The paper presents results of the analysis of emissivity of exhaust gases, based on tests special vehicles under difficult terrains conditions. There was tested Armoured Combat Vehicle "ROSOMAK", what was designed as a modular vehicle to transport people and equipment as well as combat uses too. The research were carried out on both the new vehicles, as well as the already operated on two different military training fields in Poland (Siemianowice Ślaskie, Sulejówek).

Keywords: special vehicles, Armoured Combat Vehicle "ROSOMAK", emissivity of exhaust gasses,

Streszczenie: Artykut skupia swoja uwage na analizie emisyjności spalin w trakcie eksploatacji pojazdów specjalnych $w$ warunkach poligonowych. Badaniom poddano kołowy transporter opancerzony KTO „ROSOMAK”, który jest pojazdem modułowym, zaprojektowanym jako wersja bazowa do transportu osób i sprzętu oraz jako wersja bojowa. Badania emisyjności przeprowadzono zarówno na pojazdach nowych, jak również już eksploatowanych, na dwóch różnych poligonach w kraju (Siemianowice Ślaskie, Sulejówek).
\end{abstract}

Stowa kluczowe: pojazdy specjalne, Kołowy Transporter Opancerzony „,Rosomak”, emisyjność spalin 
The evaluation of the exhaust emission level of combat vehicles under difficult... Ocena wtaściwości ekologicznych pojazdów bojowych w warunkach poligonowych...

\section{THE EVALUATION OF THE EXHAUST EMISSION LEVEL OF COMBAT VEHICLES UNDER DIFFICULT TERRAIN CONDITIONS ON THE EXEMPLE ARMORED COMBAT VEHICLE "ROSOMAK" - PART I}

\section{Introduction}

The basic factor leading to the development of technology in all industries is the need to limit its negative impact on the natural environment. The use of advanced technologies and their development forces us to constantly verify the existing operating conditions of engines and their impact on the natural environment. Therefore, intensive work has been going on for years to minimize their negative impact on the environment. Emission of toxic exhaust fumes and reduction of fuel consumption are the basic criterion determining the development directions of modern internal combustion engines. Fulfilling expectations and requirements regarding global trends in environmental protection requires the use of solutions that go beyond the area of fuel injection.

The most important future directions of development of special vehicle engines (including combat vehicles) include [4,5,6,7]:

- increasing the maximum combustion pressure to about $25 \mathrm{MPa}$;

- the use of new injection systems with a maximum injection pressure of over $200 \mathrm{MPa}$;

- increase of exhaust gas recirculation above $25 \%$;

- use of a top-up recharge;

- use of a particulate filter and DeNOx reactor (Decrease $+\mathrm{NO}_{\mathrm{x}}-\mathrm{NO}_{\mathrm{x}}$ reducing catalytic reactor) and a selective catalytic reduction system;

- implementation of new combustion systems (eg. combustion of homogeneous charge);

- extensive use of electronics in the process of engine control.

\section{Ways of determining the emissivity of special vehicles}

Determination of emissions of exhaust components from any vehicle or engine is possible in several ways:

- on the basis of engine dynamometer tests - the concentration of exhaust components is determined; considering - in accordance with the standard conversion factors for characteristic values of particular exhaust components and using measured values of engine power, it becomes possible to determine the unit emission $[\mathrm{g} / \mathrm{kWh}]$ of a given exhaust component $[2,7]$;

- based on tests on a chassis dynamometer - emission of exhaust gases is determined in a specific test drive - also on the basis of standards and regulations it is possible to determine the road emission $[\mathrm{g} / \mathrm{km} ; \mathrm{g} / \mathrm{test}]$ of a given exhaust component;

- on the basis of road tests - the concentration of gaseous components (or mass of particulate matter) is determined, and also taking into account the exhaust gas flow, also road and unit emissions of gaseous components of fumes. 
The emissivities of vehicles or engines determined on the basis of the presented methods can not be compared with each other. The method and conditions of testing are different, which results in the lack of uniformity of these methods. In the conducted research, it was assumed that the emissivity of special vehicles will concern real conditions, which is why the measurements of exhaust emissions in the conditions of road tests were used. Another reason is the fact that the results of emissions during road tests are real values for a given type of vehicles and describe their actual operational emissivity. Such conditions allow to estimate the degree of emission hazard of special vehicles and their engines during typical activities. The results of homologation tests of HDV (heavy duty vehicle) vehicles do not allow to assess their actual emission of harmful substances to the atmosphere $[1,3,8]$.

The results of exhaust emission tests in the form of $\mathrm{CO}, \mathrm{HC}, \mathrm{NO}_{\mathrm{x}}, \mathrm{CO}_{2}$, mass, distribution and particle number measurements presented in the article were divided into several stages, including:

- measurements of emissions during engine start-up:

- cold start,

- start-up in a determined thermal state,

- measurements during fixed unloaded speed (simulating the use of an internal combustion engine, e.g. as a generator):

- idle,

- $\mathrm{n}=1000 \mathrm{rpm}$,

- $\mathrm{n}=1500 \mathrm{rpm}$,

- $\mathrm{n}=2000 \mathrm{rpm}$ (these speeds were selected as representative for the combat vehicle engine based on reconnaissance road tests, which was also confirmed when using the time density characteristics),

- measurements during variable traffic conditions:

- access to the training ground in urban conditions,

- extra-urban conditions,

- polygon conditions simulating the conditions of a typical combat vehicle operation.

The characteristics of time density were used to determine the characteristics of the vehicle, the average mileage fuel consumption and the nature of emissions of individual exhaust components. This characteristic replaced the entire road cycle with several measurement points on the engine operation characteristics and enabled the determination of average mileage fuel consumption. Although this characteristic does not take into account the dynamic properties of the motor, defined by the dependence: control-torque, the published results of optimization with the use of time density characteristics show that such simplification is acceptable [8]. 
The evaluation of the exhaust emission level of combat vehicles under difficult... Ocena wtaściwości ekologicznych pojazdów bojowych w warunkach poligonowych...

\section{Research methodology}

ACV"ROSOMAK" in $8 \mathrm{x} 8$ version was tested, which is a modular armored vehicle designed for transporting people and equipment and as a combat version equipped with an armed tower with the possibility of transporting an infantry team composed of 8 soldiers in the crew compartment and a gunner and commander in the tower. Tests of the emissivity of the transporter were carried out on the basis of field driving of new vehicles (Fig. 1) at two different tactical exercise strips in Poland (Siemianowice Śląskie, Sulejówek).
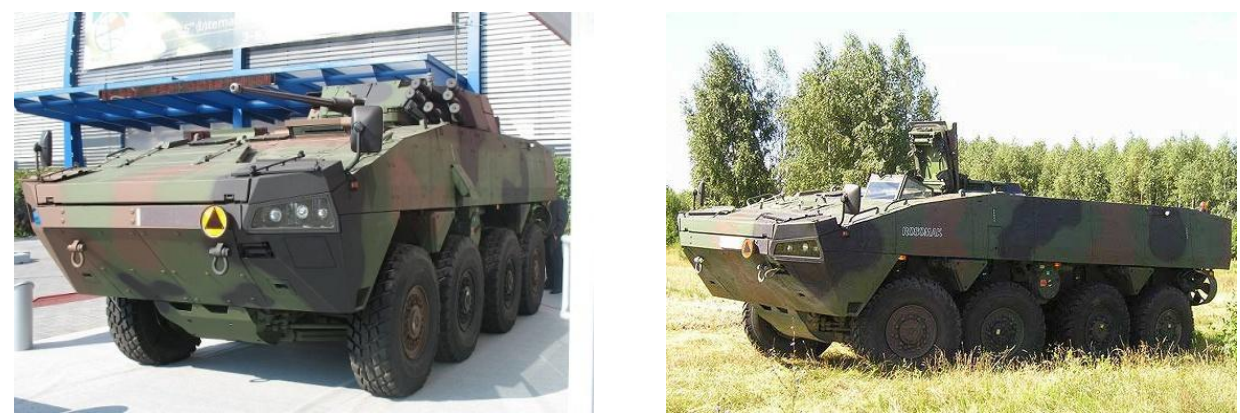

Fig. 1 ACV "ROSOMAK"

Emission measurements were made in real driving conditions. Such an approach required mounting the exhaust gas intake system on the vehicle in a manner enabling its operation. For this purpose, an exhaust gas intake system was made in the form of a conduit from the front of the vehicle - in which the exhaust system is mounted - along the vehicle, at the end there was an exhaust flow measurement system and a partial intake system for the analyzers. A mobile analyzer for measurements of SEMTECH-DS harmful exhaust gas components Sensors (Sensors EMission TECHnology) [2,6,7] was used to measure concentrations of toxic compounds. The analyzer makes it possible to measure the concentration of carbon monoxide, hydrocarbons, nitrogen oxides and carbon dioxide. The exhaust gas sampling system (Fig. 2) allows simultaneous measurement of the exhaust mass flow. Additional direct data has been added to the central unit of the analyzer from the vehicle's diagnostic system and the GPS location signal was used. SEMTECH-DS is an analyzer designed mainly for monitoring emissions of passenger cars, agricultural and construction trucks. In the DS version, it allows the emission measurement of both self-ignition engines as well and spark. All analyzer components have been designed to match the laboratory class of measuring devices as much as possible, at the same time, they were able to meet the special requirements set for devices monitoring emissions in vehicles. The fulfillment of these assumptions required maximum reduction of the mass, size and energy consumption of the device, while reducing the sensitivity to vibrations, vibrations, temperature changes and other external factors that may distort the results. 
The main advantage of the analyzer is the possibility of its easy transfer from one test to another. It can be used to monitor the emissions of other vehicles in motion as well as during static tests of engines on the dynamometer.
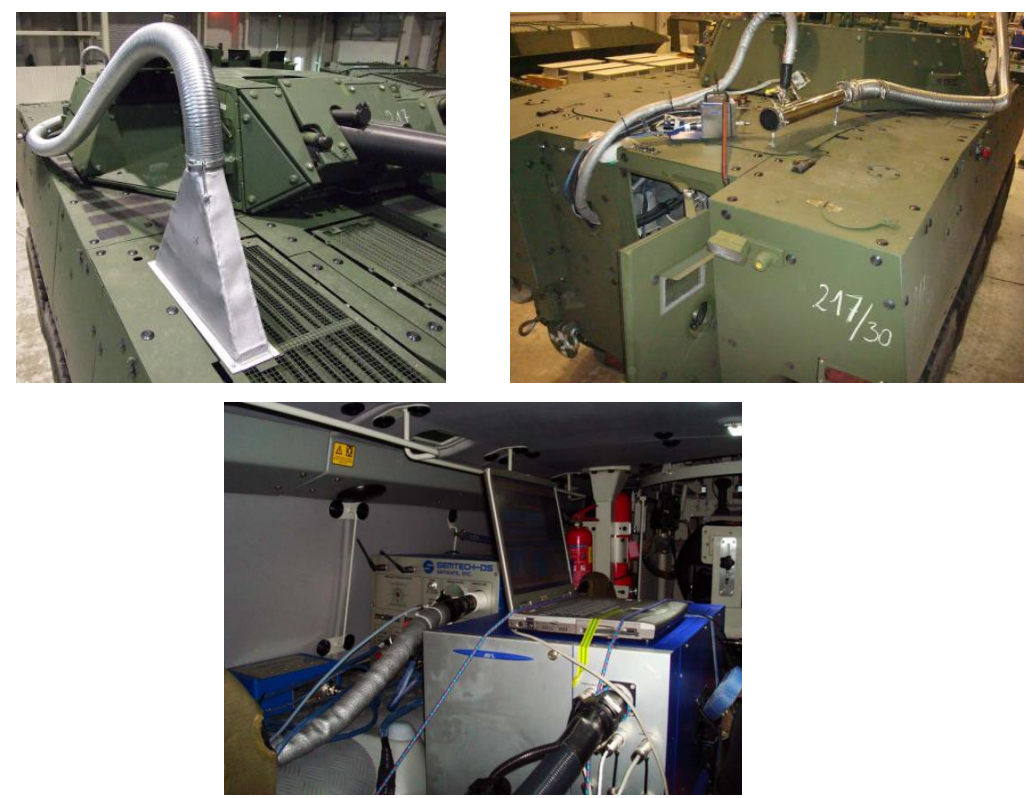

Fig. 2 Exhaust gases supply system mounted in ACV "Rosomak"

The pollutant emissions were tested in terrain conditions on two selected routes, whose road conditions, terrain and topography fully reflected the nature of the polygon (routes marked sequentially with numbers 5 and 6). The following parameters were determined:

\section{Emission of gas components}

The results of emission measurements for start-up and rotational speeds (1000, 1500 and $2000 \mathrm{rpm}$ ) are presented as measurement values of concentration and emission of harmful exhaust components $\left(\mathrm{CO}, \mathrm{HC}, \mathrm{NO}_{\mathrm{x}}, \mathrm{CO}_{2}\right)$ for several minutes of measurement. The summary of these measurements shows the average values of component concentrations and their second-order emissions.

\section{Number of particles}

The measurements of the number of solid particles were aimed at determining the number of particles emitted at a given engine work point. Measurements were made without load for warm engine start and for constant engine speeds of 1000, 1500 and $2000 \mathrm{rpm}$. The results are graphs of current measurements of the number of solid particles and average values obtained from measurements with the values of permissible measurement errors (marked as standard deviation). 
The evaluation of the exhaust emission level of combat vehicles under difficult... Ocena wtaściwości ekologicznych pojazdów bojowych w warunkach poligonowych...

\section{Dimensional distribution}

The tests consisted in determining the dimensional distribution of solid particles for individual engine work points. Measurements were made without load for warm engine start and for constant engine speeds of 1000, 1500 and $2000 \mathrm{rpm}$. The results are presented in the form of spectral characteristics of the emission of solid particles and averaged values (during the measurement) of individual particle size distributions, their area, volume and mass. The mass of the particulates was calculated using the dependence that the density of solid particles is independent of their characteristic (aerodynamic) diameter and amounts to $1000 \mathrm{~kg} / \mathrm{m}^{3}$.

\section{Ecological properties of combat vehicles in field conditions}

The presented results are a presentation of a wide fragment and multi-aspect analysis of the emissivity of the engine in conditions as close as possible to the combat conditions. An analysis of the distribution of all basic exhaust components is presented. The tests were compiled in groups concerning the standard mode of engine operation and the overboost mode (increased engine power mode). The test results concern only two routes (route 5 and 6-polygon conditions), carried out for new vehicles (research with the participation of the manufacturer ACV"ROSOMAK" in Siemianowice Śląskie).

During the transport of polygonal routes by the transporter (Fig. 3), there is a marked variation in the concentration of carbon monoxide.
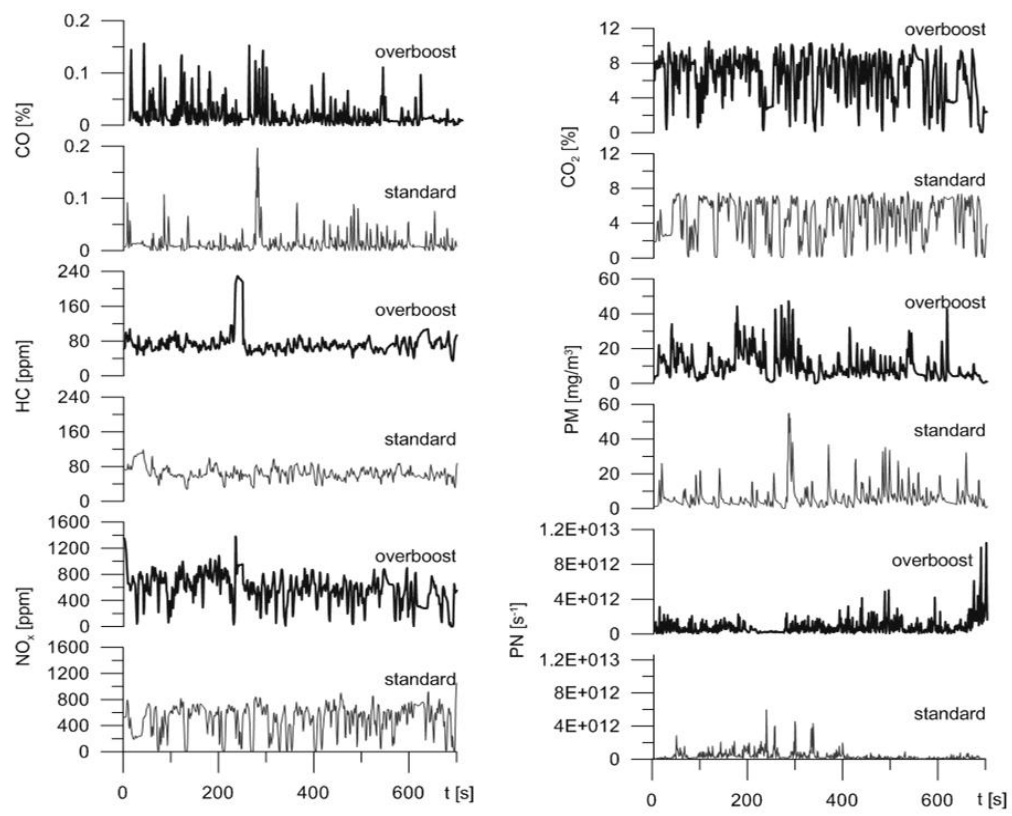

Fig. 3 The concentration of exhaust components and the number of solid particles under polygonal driving conditions 
Concentration of exhaust components In the overboost mode it assumes maximum values of about $0,15 \%$ which is on average about $0,1 \%$ higher than when traveling in standard mode (change by about 33\%). Changes in hydrocarbon concentration do not show such significant differences. The concentration of nitrogen oxides is much higher in the case of the overboost mode, which is caused by higher power and torque values of the engine. The concentration of carbon dioxide is much higher in the mode of increased torque. The particulate emission takes average values of around $20 \mathrm{mg} / \mathrm{m}^{3}$ in overboost mode, while in standard mode it is about $30 \%$ lower. Particularly important is the change in the number of solid particles. If the engine is changed from standard to overboost, the number of particles increases by an average of $100 \%$ (from $1 \cdot 10^{12}$ to $2 \cdot 10^{12} 1 / \mathrm{s}$ ).

During the passage of selected routes, a significant increase in the mass emission of carbon monoxide in the overboost mode was observed (Fig. 4). The route profile meant that the emission in standard work mode does not exceed $10 \mathrm{mg} / \mathrm{s}$. In overboost mode, even when running on loose gear (increased speed), values above $50 \mathrm{mg} / \mathrm{s}$ have been recorded. $\mathrm{CO}$ emission values in the range of partial rotational speeds and loads are in the range $50-150 \mathrm{mg} / \mathrm{s}$. This means more than a 15-fold increase in carbon monoxide emissions during these trips and number of particulates under polygonal driving conditions.
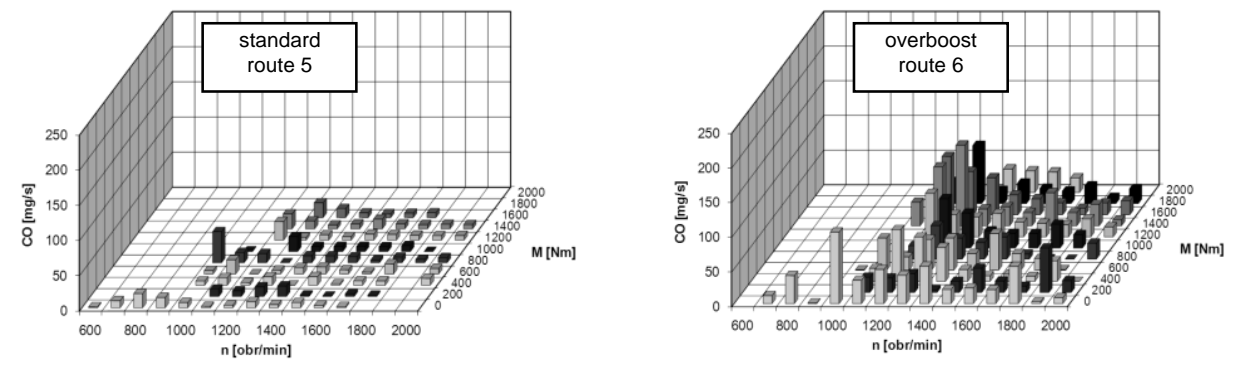

Fig. 4 Intensity of mass emission of carbon monoxide during polygonal driving

Emission of hydrocarbons during the route 5 (standard) is at the level of 1-4 mg/s (Fig. 5). This means the lowest $\mathrm{HC}$ emission values on all polygonal routes. Route 6 , overburdened, results in an $\mathrm{HC}$ emission of $5-15 \mathrm{mg} / \mathrm{s}$, increasing emissions by over $300 \%$ (taking into account the maximum values from both routes).
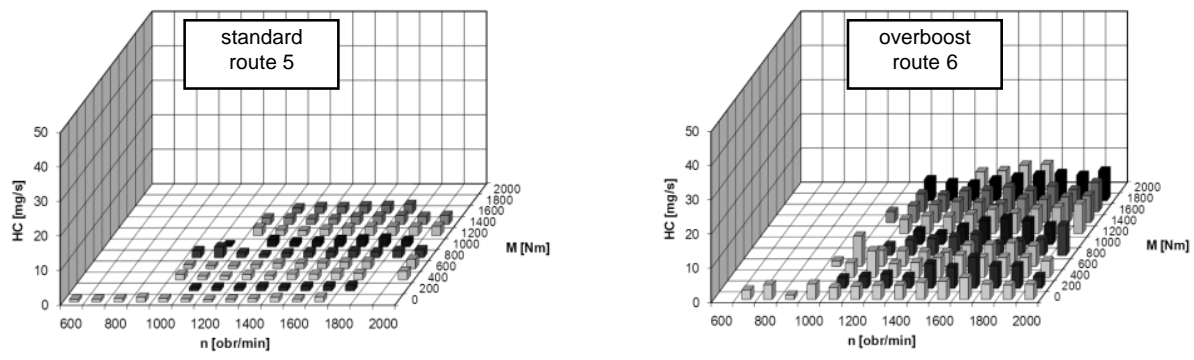

Fig. 5 Intensity of mass emission of hydrocarbons during polygonal driving 
The evaluation of the exhaust emission level of combat vehicles under difficult... Ocena wtaściwości ekologicznych pojazdów bojowych w warunkach poligonowych...

The emission of nitrogen oxides differs significantly during the passage of selected routes (Fig. 6). During the first route $\mathrm{NO}_{\mathrm{x}}$ reaches small values: up to $80 \mathrm{mg} / \mathrm{s}$. Higher values were obtained in the range of maximum loads and rotational speeds. During partial and minimum loads, the emission of nitrogen oxides decreases to about $20 \mathrm{mg} / \mathrm{s}$. Using the overboost mode results in a significant increase in $\mathrm{NO}_{\mathrm{x}}$ emissions. During engine idling, values reach $50-150 \mathrm{mg} / \mathrm{s}$. Increasing the load also results in increased emissions: maximum values are around $300 \mathrm{mg} / \mathrm{s}$ in the high engine load range.
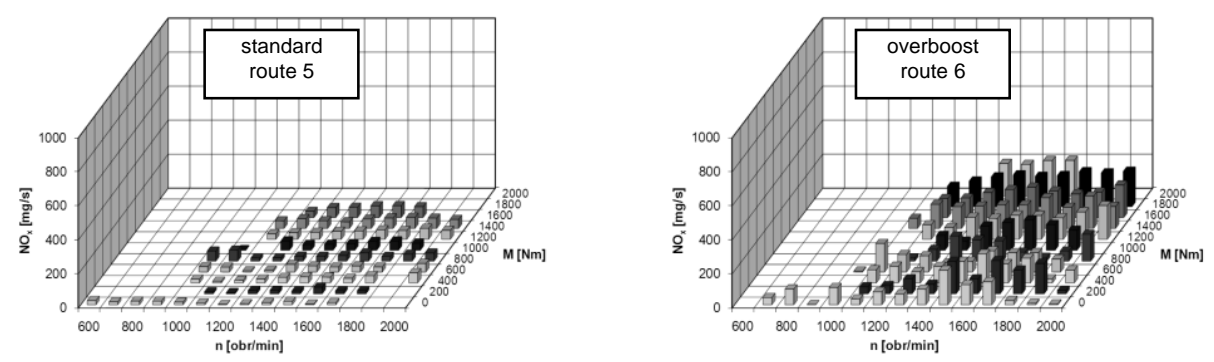

Fig. 6 Intensity of mass emission of nitrogen oxides during polygonal driving

The emission of solid particles depends on the mode of operation of the internal combustion engine (Fig. 7). In standard mode (route 5), the values achieved reach about $1-2 \mathrm{mg} / \mathrm{s}$. In overboost mode, they are much larger: the average values are around $3-4 \mathrm{mg} / \mathrm{s}$. This means an increase of over $100 \%$.
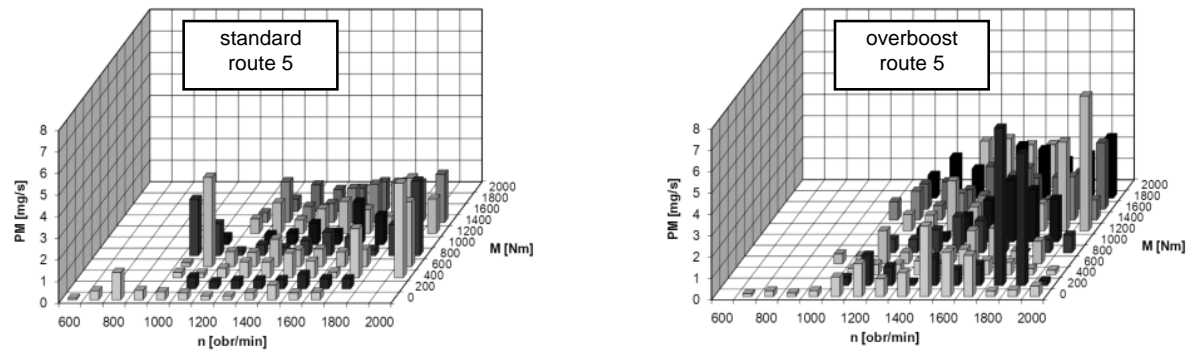

Fig. 7 Intensity of mass emission of solid particles during polygonal driving

The number of particulates, on dedicated routes reaches different values. During standard driving mode the number is proportional to the speed of rotation. This means increasing the exhaust gas flow and the associated increase in the number of solid particles. However, in the overboost mode, it is not possible to observe a similar trend. At partial loads and speeds, the number of particles reaches maximum values, then the number decreases as the speed increases. The increase in the load does not affect the change in the number of solid particles (a similar tendency was observed for the standard mode of operation of the engine). 

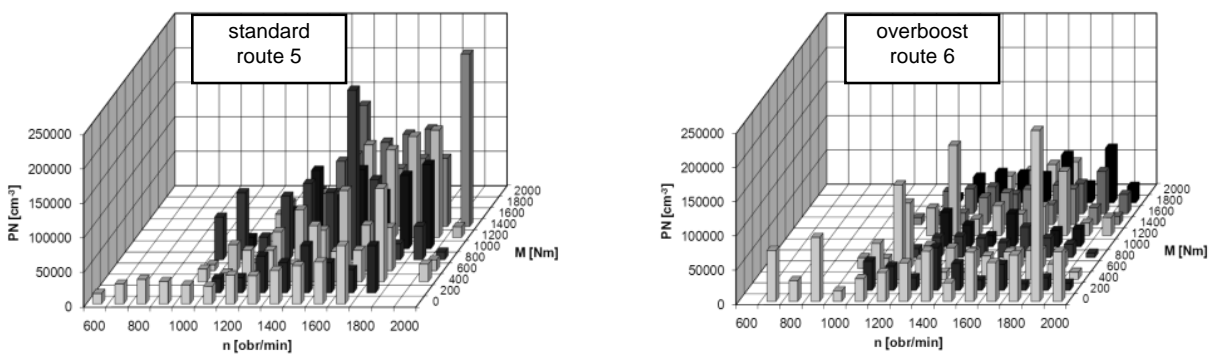

Fig. 8 Number of particles in polygonal conditions

\section{Summary}

Considering the variability of emissions during the two modes of operation of the internal combustion engine of the new ACV"ROSOMAK", the following conclusions were drawn from this fragment of field tests:

- Overboost mode causes a significant increase in carbon monoxide emissions, especially in the range of partial rotational speeds and loads of the combat vehicle's combustion engine. The obtained changes reach values of over $200 \%$ at selected points of the engine's operation.

- The operation of the engine in the overboost mode significantly increases the emission of hydrocarbons. Changes reach over $100 \%$. The highest emission values are obtained for the maximum values of speed and loads.

- The emission of nitrogen oxides is about $50 \%$ higher in overboost compared to the standard driving mode. It should be noted that the NOx emission does not reach the highest values for the maximum rotational speeds.

- The emission of solid particles does not show a clear trend depending on the way the engine is used. It should be noted that the increased emissions during the maximum loads in the overboost mode are about $80 \%$. In this mode, both increasing the speed and load, increases the emission of solid particles. This tendency is not observed for the standard engine operation mode.

- The number of solid particles decreases in the overboost mode. The regularity appears in the form of an increased number of solid particles in the vicinity of partial rotational speeds with their simultaneous decrease when increasing this speed. The load has little or no effect on the number of solid particles.

These conclusions do not fully cover the issue of exhaust emissions of combat vehicles. The next step should be conducting similar tests for the vehicle in operation and conducting a comparative analysis of the obtained results.

\section{References}

[1] Directive 94/12/EC of the European Parliament and the Council of 23 March 1994: Relating to measures to be taken against air pollution by emissions from motor vehicles and Amending Directive 70/220/EEC; Commission Directive 96/44/EC of 1 July 1996 Directive 96/69/EC of 8 October 1996. 
The evaluation of the exhaust emission level of combat vehicles under difficult... Ocena wtaściwości ekologicznych pojazdów bojowych w warunkach poligonowych...

[2] Ensfield C., Bachman L.J., Erb A., Bynum C.: Evaluating real-world fuel economy on heavy duty vehicles using a portable emissions measurement system, SAE Technical Paper Series 2006-01-3543.

[3] Merkisz J., Mazurek S.: Pokładowe systemy diagnostyczne pojazdów samochodowych. Wydawnictwa Komunikacji i Łączności, Warszawa 2009.

[4] Merkisz J., Pielecha I., Pielecha J.: Gaseous and PM emission from combat vehicle engines during start and warm-up. SAE International Powertrains, Fuels and Lubricants Meeting, San Diego, SAE Technical Paper Series 201001-2283.

[5] Merkisz J., Pielecha J., Bielaczyc P.: Stan cieplny silnika spalinowego a emisja związków szkodliwych. Wydawnictwo Politechniki Poznańskiej, Poznań 2001.

[6] Merkisz J., Pielecha J.: Analysis of Particle Concentrations and Smoke in Common-Rail Diesel Engine, SAE Technical Paper Series 2008-01-1743.

[7] Merkisz J., Radzimirski S., Pielecha J.: Pragmatyczne podstawy ochrony powietrza atmosferycznego $\mathrm{w}$ transporcie drogowym. Wydawnictwo Politechniki Poznańskiej, Poznań 2009.

[8] Schwarz E., Danielson E., Bryzik W., Keelan T., Hakim N.: NATO qualification test of Detroit Diesel 8V71-TA engine at 530 BHP with advanced ceramic components. SAE Technical Paper Series 2000-01-0524.

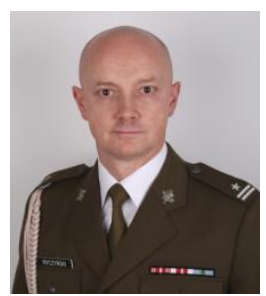

Maj. Eng. Jacek Ryczyński, DSc. Assistant Professor Department of Logistic Faculty of Management Military University of Land Forces, Wroclaw, Poland (Share 50\%).

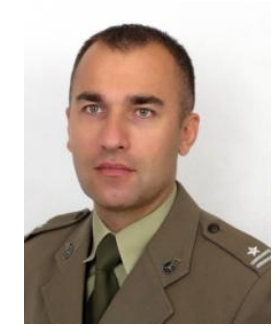

Maj. Eng. Maciej Szukalski, DSc. Assistant Professor Head of Department of Logistic Faculty of Management Military University of Land Forces, Wroclaw, Poland (Share 50\%). 


\section{OCENA WLAŚCIWOŚCI EKOLOGICZNYCH POJAZDÓW BOJOWYCH W WARUNKACH POLIGONOWYCH NA PRZYKLADZIE KOLOWEGO TRANSPORTERA OPANCERZONEGO KTO „ROSOMAK” - CZEŚŚ I}

\section{Wstęp}

Podstawowym czynnikiem prowadzącym do rozwoju techniki i technologii we wszystkich dziedzinach przemysłu jest konieczność ograniczania jego negatywnego wpływu na środowisko naturalne. Stosowanie zaawansowanych technologii i ich rozwój, zmusza do ciągłej weryfikacji istniejących warunków pracy silników oraz ich skutków oddziaływania na środowisko naturalne. Dlatego od lat trwają intensywne prace, mające na celu zminimalizowanie ich negatywnego oddziaływania na środowisko. Emisja związków toksycznych spalin i ograniczanie zużycia paliwa są podstawowym kryterium wyznaczającym kierunki rozwoju współczesnych silników spalinowych. Spełnienie oczekiwań i wymagań odnośnie światowych trendów w kwestii ochrony środowiska wymaga stosowania rozwiązań wykraczających poza obszar wtrysku paliwa.

Do najważniejszych przyszłościowych kierunków rozwoju silników pojazdów specjalnych (w tym wozów bojowych) należy zaliczyć $[4,5,6,7]$ :

- zwiększenie maksymalnego ciśnienia spalania do około $25 \mathrm{MPa}$;

- zastosowanie nowych układów wtrysku o maksymalnym ciśnieniu wtryskiwanego paliwa ponad $200 \mathrm{MPa}$;

- zwiększenie recyrkulacji spalin powyżej $25 \%$;

- stosowanie doładowania zakresowego;

- zastosowanie filtra cząstek stałych i reaktora DeNOx (Decrease + NOx reaktor katalityczny obniżający NOx) oraz układu selektywnej redukcji katalitycznej;

- wdrażanie nowych systemów spalania (np. spalanie ładunku homogenicznego);

- szerokie wykorzystanie elektroniki $\mathrm{w}$ procesie sterowania i kontroli pracy silnika.

\section{Sposoby określania emisyjności pojazdów specjalnych}

Wyznaczenie emisji składników spalin z dowolnego pojazdu lub silnika możliwe jest kilkoma sposobami:

- na podstawie badań na hamowni silnikowej - określa się stężenie składników spalin; uwzględniając - zgodnie $\mathrm{z}$ normą - przeliczniki dotyczące charakterystycznych wielkości poszczególnych składników spalin oraz wykorzystując zmierzone wartości mocy silnika, możliwe staje się wyznaczenie emisji jednostkowej $[\mathrm{g} /(\mathrm{kWh})]$ danego składnika spalin [2,7]; 
The evaluation of the exhaust emission level of combat vehicles under difficult... Ocena wtaściwości ekologicznych pojazdów bojowych w warunkach poligonowych...

- na podstawie badań na hamowni podwoziowej - określa się emisję spalin w określonym teście jezdnym - również na podstawie norm i regulaminów możliwe jest określenie emisji drogowej $[\mathrm{g} / \mathrm{km}$; g/test] danego składnika spalin;

- na podstawie badań drogowych - określa się stężenie składników gazowych (lub masę cząstek stałych), a przy uwzględnieniu wydatku spalin również emisję drogową i jednostkową gazowych składników spalin.

Emisyjności pojazdów lub silników określone na podstawie przedstawionych metod nie mogą być ze sobą porównywane. Sposób i warunki przeprowadzania prób są odmienne, co powoduje brak ujednolicenia tych metod. W prowadzonych badaniach przyjęto, że emisyjność pojazdów specjalnych dotyczyć będzie warunków rzeczywistych, dlatego wykorzystano pomiary emisji spalin w warunkach badań drogowych. Kolejnym powodem jest fakt, że wyniki emisji podczas badań drogowych są wartościami rzeczywistymi dla danego typu pojazdów i opisują ich rzeczywistą emisyjność eksploatacyjną. Warunki takie pozwalają oszacować stopień zagrożenia emisyjnego pojazdów specjalnych i ich silników podczas typowych działań. Wyniki z testów homologacyjnych silników pojazdów HDV (heavy duty vehicle) nie pozwalają ocenić ich rzeczywistej emisji substancji szkodliwych do atmosfery $[1,3,8]$.

Prezentowane $\mathrm{w}$ artykule wyniki badań emisji spalin w postaci pomiarów stężenia: $\mathrm{CO}, \mathrm{HC}, \mathrm{NOx}, \mathrm{CO}_{2}$, pomiarów masy, rozkładu oraz liczby cząstek stałych, podzielono na kilka etapów, do których zaliczono:

6. pomiary emisji podczas rozruchu silnika:

- zimny rozruch,

- rozruch w ustalonym stanie cieplnym,

7. pomiary podczas ustalonych prędkości obrotowej bez obciążenia (symulujące wykorzystanie silnika spalinowego, np. jako generatora prądotwórczego):

- bieg jałowy,

- $\mathrm{n}=1000 \mathrm{obr} / \mathrm{min}$,

- $\mathrm{n}=1500 \mathrm{obr} / \mathrm{min}$,

- $\mathrm{n}=2000 \mathrm{obr} / \mathrm{min}$ (prędkości te wybrano jako reprezentatywne dla silnika pojazdu bojowego na podstawie rozpoznawczych badań drogowych, co potwierdzono również podczas wykorzystania charakterystyki gęstości czasowej),

8. pomiary podczas zmiennych warunków ruchu:

- dojazd do poligonu w warunkach miejskich,

- warunki pozamiejskie,

- warunki poligonowe symulujące warunki typowej pracy pojazdu bojowego.

Charakterystyka gęstości czasowej służyła do określenia właściwości pojazdu, średniego przebiegowego zużycia paliwa oraz charakteru emisji poszczególnych składników spalin. Charakterystyka ta zastępowała cały cykl drogowy kilkunastoma punktami pomiarowymi na charakterystyce pracy silnika i umożliwiała wyznaczenie średniego przebiegowego zużycia paliwa. 
Wprawdzie charakterystyka ta nie uwzględnia właściwości dynamicznych silnika, zdefiniowanych zależnością: sterowanie-moment obrotowy, to publikowane wyniki optymalizacji z użyciem charakterystyki gęstości czasowej pokazują, że uproszczenie takie jest dopuszczalne [8].

\section{Obiekt i metodyka badań}

Badaniom poddano transporter opancerzony KTO „ROSOMAK” w wersji 8x8, który jest modułowym pojazdem opancerzonym przeznaczonym do transportu osób i sprzętu oraz jako wersja bojowa wyposażona w uzbrojoną wieżę z możliwością przewożenia drużyny piechoty w składzie 8 żołnierzy w przedziale załogowym oraz działonowy i dowódca w wieży.

Badania emisyjności kołowego transportera, prowadzono na podstawie testów poligonowych pojazdów nowych (rys. 1) na dwóch różnych poligonach w kraju (Siemianowice Śląskie, Sulejówek).
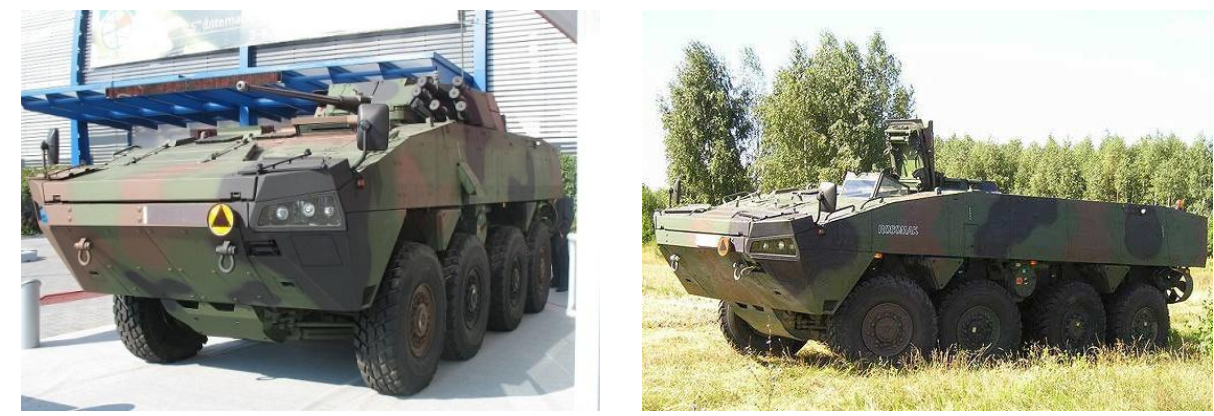

\section{Rys. 1 Obiekt badań}

Pomiarów emisji składników spalin dokonano w rzeczywistych warunkach jazdy. Podejście takie wymagało zamontowania układu poboru spalin na pojeździe w sposób umożliwiający jego eksploatację. W tym celu wykonano układ poboru spalin w postaci przewodu od przedniej części pojazdu - w której zamontowany jest układ wylotowy - wzdłuż pojazdu, na końcu znajdował się układ pomiaru natężenia przepływu spalin i układ częściowego poboru do analizatorów pomiarowych. Do pomiarów stężenia związków toksycznych wykorzystano mobilny analizator do pomiarów składników szkodliwych spalin SEMTECH-DS firmy Sensors (ang. Sensors EMission TECHnology ) [2,6,7].

Analizator umożliwia pomiar stężenia tlenku węgla, węglowodorów, tlenków azotu oraz dwutlenku węgla. Układ poboru próbki spalin (rys. 2) pozwala jednocześnie na pomiar masowego natężenia przepływu spalin. Do jednostki centralnej analizatora doprowadzono dodatkowo dane bezpośrednio przesyłane z systemu diagnostycznego pojazdu oraz wykorzystano sygnał lokalizacji GPS. 
The evaluation of the exhaust emission level of combat vehicles under difficult... Ocena wtaściwości ekologicznych pojazdów bojowych w warunkach poligonowych...

SEMTECH-DS jest analizatorem przeznaczonym głównie do monitorowania emisji pojazdów osobowych, ciężarowych rolniczych i budowlanych.

W wersji DS umożliwia pomiar emisji, zarówno silników o zapłonie samoczynnym jak i iskrowym. Wszystkie podzespoły analizatora zostały zaprojektowane tak, aby jak najbardziej odpowiadały klasie laboratoryjnej urządzeń pomiarowych, a jednocześnie mogły sprostać specjalnym wymaganiom stawianym urządzeniom monitorującym emisję $\mathrm{w}$ pojazdach. Spełnienie tych założeń wymagało maksymalnego obniżenia masy, wielkości i zużycia energii przez urządzenie przy jednoczesnym zredukowaniu wrażliwości na drgania, wibracje, zmiany temperatury i inne czynniki zewnętrze mogące zniekształcić wyniki. Główną zaletą analizatora jest możliwość jego łatwego przemieszczania $\mathrm{z}$ jednego testu do drugiego. Może być on używany do monitorowania emisji innych pojazdów będących w ruchu, jak i również podczas statycznych testów silników na hamowni.
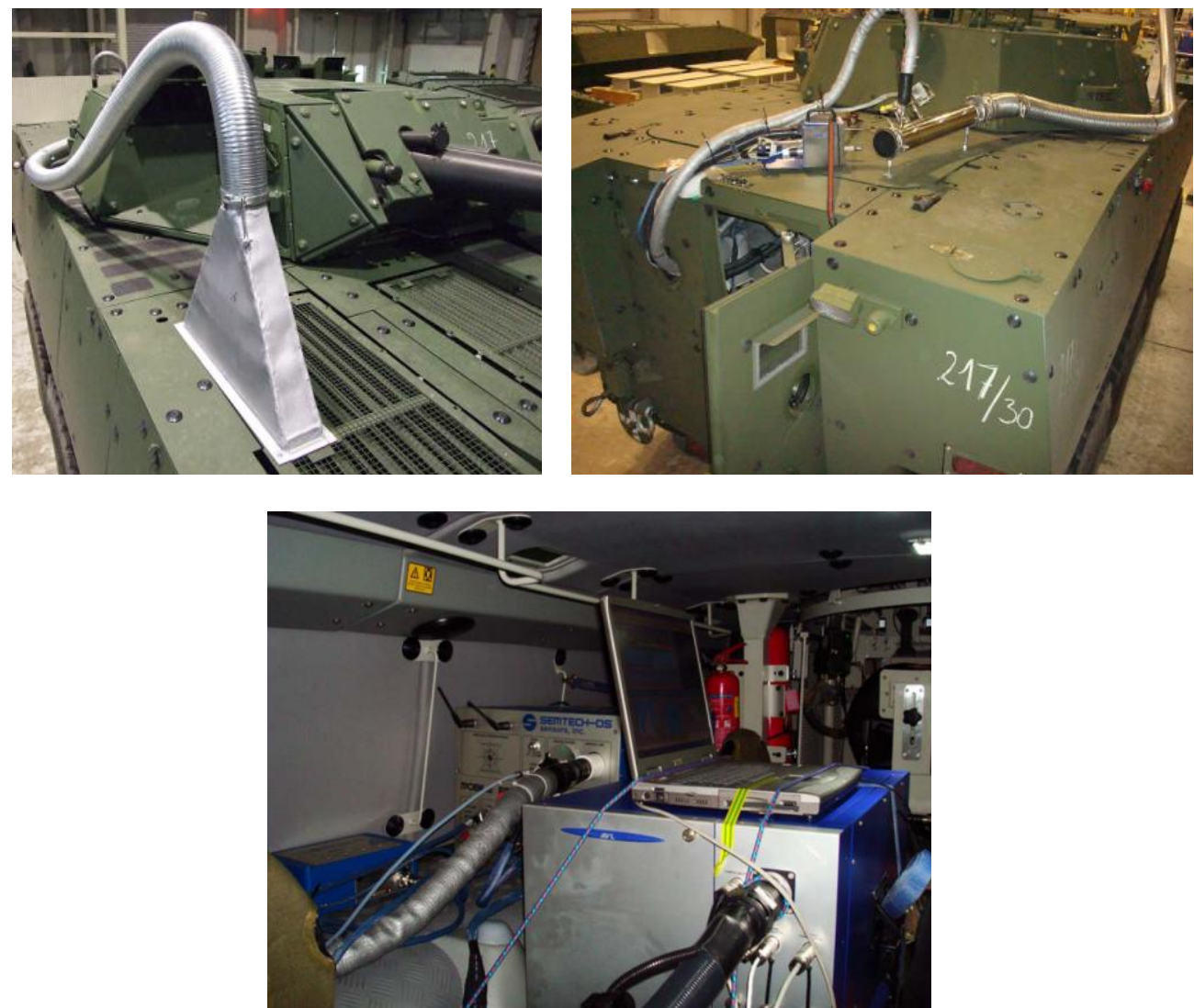

Rys. 2 Uktad poboru spalin $i$ widok analizatora SEMTECH-DS w KTO Rosomak 
Badania emisji składników szkodliwych spalin przeprowadzono w warunkach terenowych na dwóch wybranych trasach, których warunki drogowe, ukształtowanie terenu i topografia w pełni odzwierciedlały charakter poligonowy (trasy oznaczonych kolejno numerami 5 i 6). Określano następujące parametry:

\section{Emisja skladników gazowych spalin}

Wyniki pomiarów emisji dla rozruchu i prędkości obrotowych (1000, 1500 i 2000 obr/min) przedstawiono jako wartości pomiarowe stężenia i emisji składników szkodliwych spalin (CO, HC, NOx, CO2) dla kilku minut pomiaru. $\mathrm{W}$ podsumowaniu tych pomiarów przedstawiono wartości średnie: stężenia składników oraz ich emisji sekundowej.

\section{Liczba czạstek}

Pomiary liczby cząstek stałych miały na celu określenie liczby cząstek emitowanych w danym punkcie pracy silnika. Pomiarów dokonano bez obciążenia dla ciepłego rozruchu silnika oraz dla stałych prędkości obrotowych silnika 1000 , 1500 oraz $2000 \mathrm{obr} / \mathrm{min}$. Rezultat to wykresy bieżących pomiarów liczby cząstek stałych oraz wartości średnie uzyskane z pomiarów z naniesionymi wartościami dopuszczalnych błędów pomiarów (zaznaczone jako odchylenie standardowe).

\section{Rozklad wymiarowy}

Badania polegały na określeniu rozkładu wymiarowego cząstek stałych dla poszczególnych punktów pracy silnika. Pomiarów dokonano bez obciążenia dla ciepłego rozruchu silnika oraz dla stałych prędkości obrotowych silnika 1000, 1500 oraz $2000 \mathrm{obr} / \mathrm{min}$. Rezultaty przedstawiono w postaci charakterystyki widmowej emisji rozkładu wymiarowego cząstek stałych oraz wielkości uśrednionych (w czasie pomiaru) poszczególnych rozkładów wielkości cząstek ich pola powierzchni, objętości oraz masy. Masę cząstek stałych obliczano z wykorzystaniem zależności, że gęstość cząstek stałych jest niezależna od ich średnicy charakterystycznej (aerodynamicznej) i wynosi $1000 \mathrm{~kg} / \mathrm{m}^{3}$.

\section{Emisyjność wozów bojowych w warunkach poligonowych}

Przedstawione wyniki stanowią prezentację fragmentu szerokiej i wieloaspektowej analizy emisyjności silnika w warunkach możliwie silnie zbliżonych do warunków bojowych. Przedstawiona została analiza rozkładów wszystkich podstawowych składników spalin. Badania zestawiono w grupach dotyczących trybu standardowej pracy silnika oraz trybu overboost (tryb zwiększonej mocy silnika). Wyniki badań tyczą się tylko dwóch tras przejazdu (trasa 5 i 6-warunki poligonowe), prowadzonych dla pojazdów nowych (badania z udziałem producenta „Rosomaka” w Siemianowicach Śląskich). 
The evaluation of the exhaust emission level of combat vehicles under difficult... Ocena wtaściwości ekologicznych pojazdów bojowych w warunkach poligonowych...

W trakcie pokonywania przez transporter tras poligonowych (rys. 3) widoczne jest znaczne zróżnicowanie stężenia tlenku węgla.
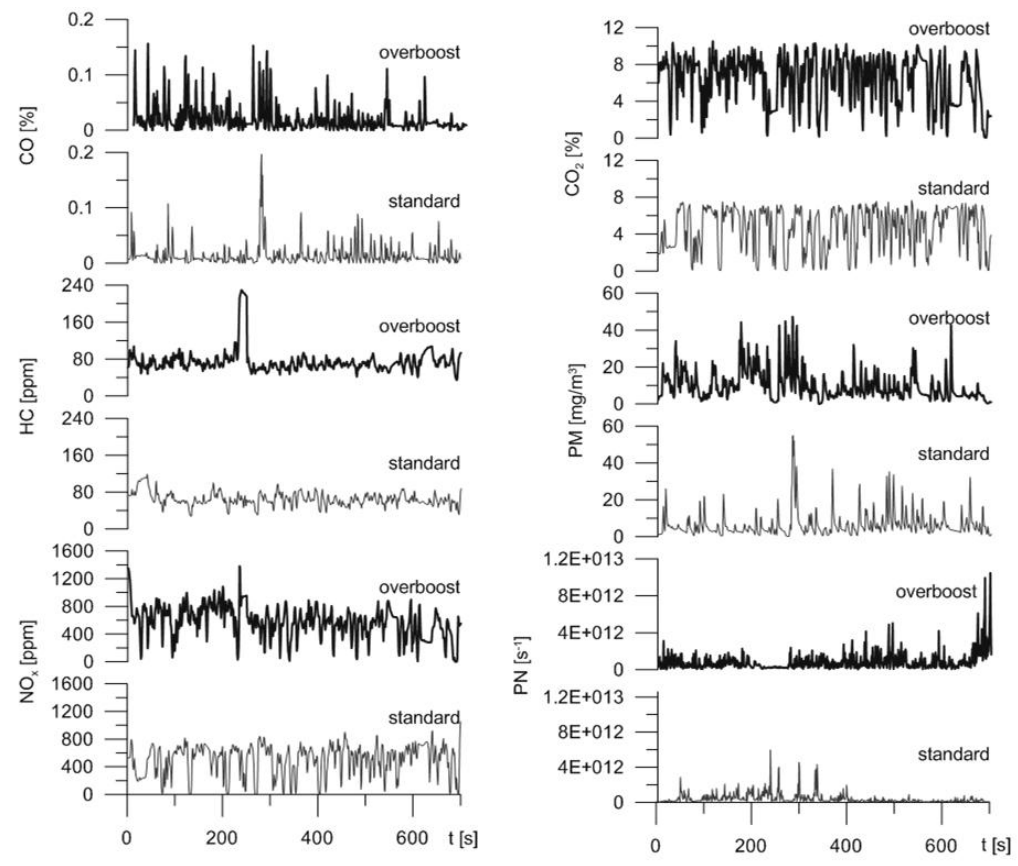

Rys. 3 Stężenie składników spalin i liczba cząstek statych $w$ warunkach jazdy poligonowej

W trybie overboost przyjmuje on wartości maksymalne około $0,15 \%$ co jest średnio o około $0,1 \%$ większą wartością niż podczas przejazdu w trybie standard (zmiana o około 33\%). Zmiany stężenia węglowodorów nie wykazują tak istotnych różnic. Stężenie tlenków azotu jest znacznie większe w przypadku trybu overboost, co jest powodowane większymi wartościami mocy i momentu obrotowego silnika. Stężenie dwutlenku węgla jest znacznie większe w trybie zwiększonego momentu obrotowego. Emisja cząstek stałych przyjmuje średnie wartości około $20 \mathrm{mg} / \mathrm{m}^{3}$ w trybie overboost, natomiast w trybie standardowym jest o około $30 \%$ mniejsza. Szczególnie istotna jest zmiana liczby cząstek stałych. W przypadku zmiany trybu pracy silnika ze standardowego do overboost następuje zwiększenie liczby cząstek średnio o $100 \%\left(\mathrm{z} 1 \cdot 10^{12}\right.$ do $\left.2 \cdot 10^{12} 1 / \mathrm{s}\right)$.

Podczas przejazdu wybranymi trasami zaobserwowano znaczne zwiększenie natężenia masowej emisji tlenku węgla w trybie overboost (rys. 4). Profil trasy powodował, że emisja $\mathrm{w}$ trybie standardowej pracy nie przekracza wartości $10 \mathrm{mg} / \mathrm{s}$. W trybie overboost nawet podczas pracy na biegu luzem (podwyższona prędkość obrotowa) odnotowano wartości powyżej $50 \mathrm{mg} / \mathrm{s}$. 
Wartości emisji CO w zakresie częściowych prędkości obrotowych i obciążeń zawierają się w przedziale $50-150 \mathrm{mg} / \mathrm{s}$. Oznacza to ponad 15-krotne zwiększenie emisji tlenku węgla podczas tych przejazdów.
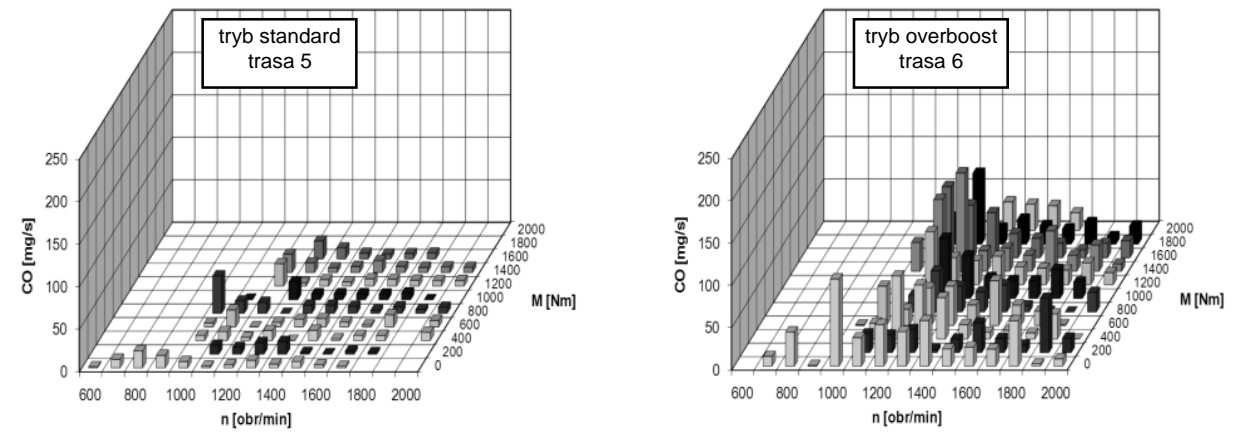

Rys. 4 Natężenie masowej emisji tlenku węgla w warunkach jazdy poligonowej

Emisja węglowodorów podczas przejazdu trasą 5 (standard) kształtuje się na poziomie $1-4 \mathrm{mg} / \mathrm{s}$ (rys. 5). Oznacza to najmniejsze wartości emisji $\mathrm{HC}$ we wszystkich trasach przejazdu poligonowego. Trasa 6 pokonana w trybie overboost skutkuje emisją $\mathrm{HC}$ na poziomie $5-15 \mathrm{mg} / \mathrm{s}$ co stanowi zwiększenie emisji o ponad $300 \%$ (biorąc pod uwagę wartości maksymalne z obu tras przejazdu).
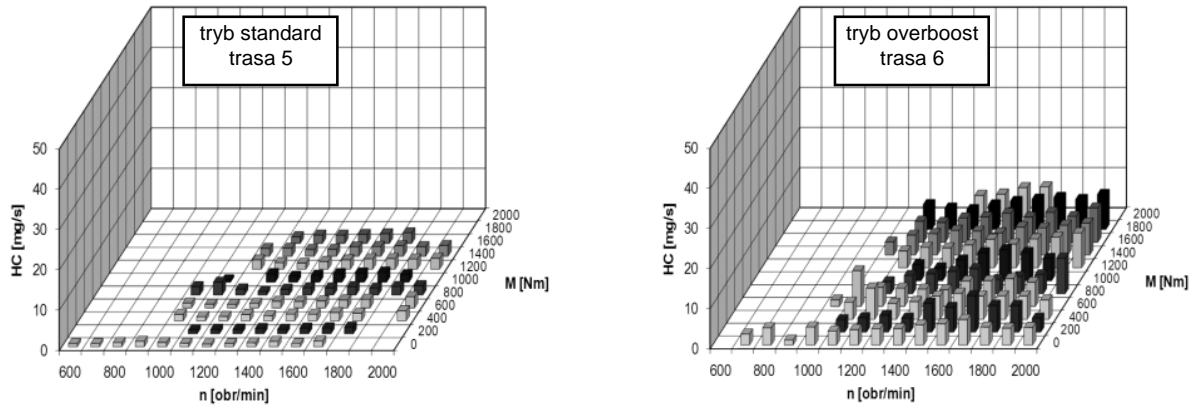

Rys. 5 Natężenie masowej emisji węglowodorów w warunkach jazdy poligonowej

Emisja tlenków azotu znacznie różni się podczas przejazdu wybranymi trasami (rys. 6). Podczas przejazdu pierwszej trasy $\mathrm{NO}_{\mathrm{x}}$ osiągają niewielkie wartości: maksymalnie do $80 \mathrm{mg} / \mathrm{s}$. Wyższe wartości uzyskiwano w zakresie maksymalnych obciążeń i prędkości obrotowych. Podczas obciążeń częściowych i minimalnych emisja tlenków azotu zmniejsza się do około $20 \mathrm{mg} / \mathrm{s}$. Stosowanie trybu overboost powoduje znaczne zwiększenie emisji $\mathrm{NO}_{\mathrm{x}}$. Podczas biegu luzem silnika wartości uzyskują poziom $50-150 \mathrm{mg} / \mathrm{s}$. Zwiększenie obciążenia skutkuje również zwiększeniem emisji: maksymalne wartości wynoszą około $300 \mathrm{mg} / \mathrm{s} \mathrm{w}$ zakresie dużych obciążeń silnika. 
The evaluation of the exhaust emission level of combat vehicles under difficult... Ocena waaściwości ekologicznych pojazdów bojowych w warunkach poligonowych...
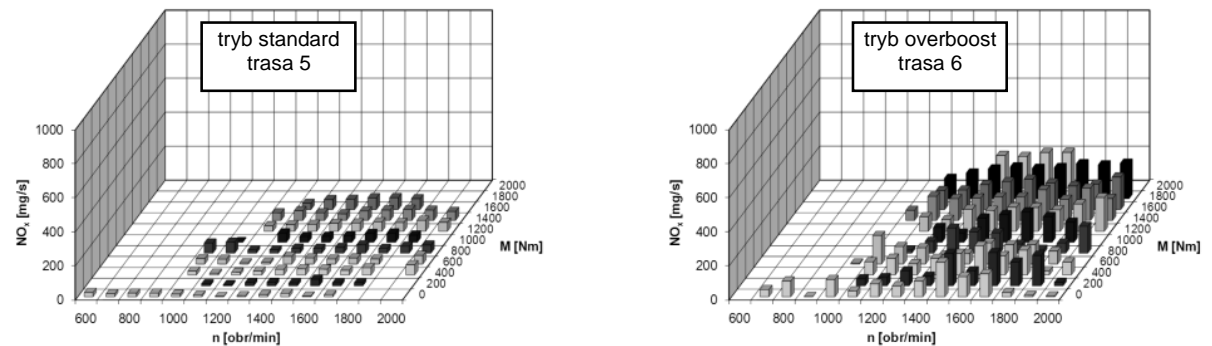

Rys. 6 Natężenie masowej emisji tlenków azotu w warunkach jazdy poligonowej

Emisja cząstek stałych zależy od sposobu pracy silnika spalinowego (rys. 7). W trybie standardowym (trasa 5) osiągane wartości uzyskują poziom około 1-2 $\mathrm{mg} / \mathrm{s}$. W trybie overboost są znacznie większe: średnie wartości to przedział około 3-4 mg/s. Oznacza to przyrost o ponad $100 \%$.
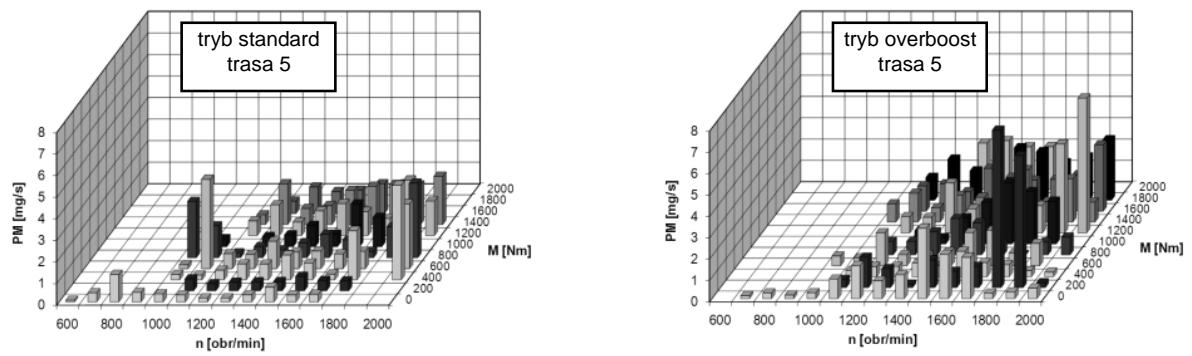

Rys. 7 Natężenie masowej emisji cząstek stałych $w$ warunkach jazdy poligonowej

Liczba cząstek stałych podczas przejazdu dedykowanymi trasami osiąga odmienne wartości. Podczas trybu standardowej jazdy liczba jest proporcjonalna do prędkości obrotowej. Oznacza to zwiększenie wydatku spalin i związane z tym zwiększenie liczby cząstek stałych. Jednak $\mathrm{w}$ trybie overboost taka nie jest możliwe zaobserwowanie podobnej tendencji. Przy częściowych obciążeniach i prędkościach obrotowych liczba cząstek osiąga wartości maksymalne, następie wraz ze zwiększeniem prędkości liczba ulega zmniejszeniu. Zwiększenie obciążenia nie wpływa na zmianę liczby cząstek stałych (podobną tendencję zaobserwowano dla standardowego trybu pracy silnika).
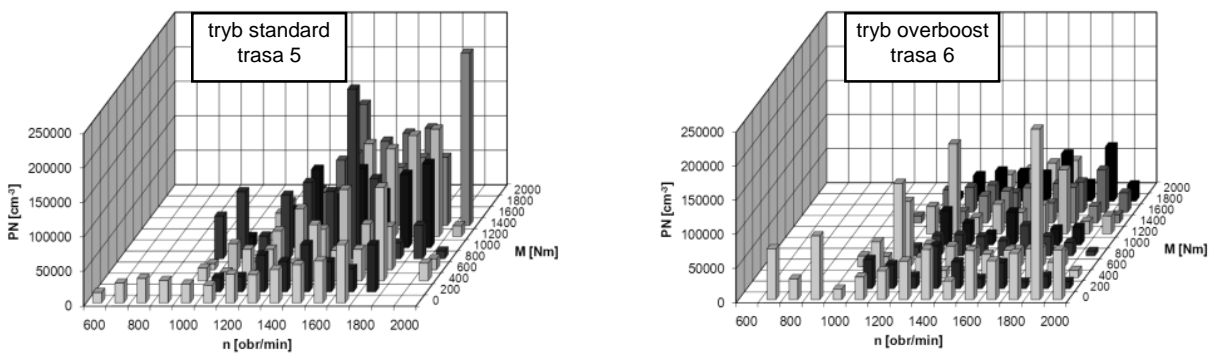

Rys. 8. Liczba cząstek statych w warunkach jazdy poligonowej 


\section{Podsumowanie i wnioski}

Biorąc pod uwagę zmienność emisji podczas dwóch trybów pracy silnika spalinowego nowego transportera KTO „ROSOMAK”, sformułowano następujące wnioski wynikające $\mathrm{z}$ tego fragmentu badań poligonowych:

- Tryb overboost powoduje znaczne zwiększenie emisji tlenku węgla szczególnie w zakresie częściowych prędkości obrotowych i obciążeń silnika spalinowego wozu bojowego. Uzyskiwane zmiany osiągają wartości ponad 200\% w wybranych punktach pracy silnika.

- Praca silnika w trybie overboost w sposób znaczący zwiększa emisję węglowodorów. Zmiany osiągają poziom ponad $100 \%$. Największe wartości emisji uzyskuje się dla maksymalnych wartości prędkości i obciążeń.

- Emisja tlenków azotu uzyskuje wartości o około 50\% większe w trybie overboost $\mathrm{w}$ porównaniu do standardowego trybu jazdy. Należy zauważyć, że emisja $\mathrm{NO}_{\mathrm{x}}$ nie osiąga wartości największych dla maksymalnych prędkości obrotowych.

- Emisja cząstek stałych nie wykazuje jednoznacznej tendencji w zależności od sposobu eksploatacji silnika. Należy odnotować fakt zwiększonej emisji podczas obciążeń maksymalnych $\mathrm{w}$ trybie overboost o około $80 \%$. W tym trybie zarówno zwiększenie prędkości obrotowej jak i obciążenia, powoduje zwiększenie emisji cząstek stałych. Tendencji takiej nie obserwuje się dla standardowego trybu pracy silnika.

- Liczba cząstek stałych zmniejsza się w trybie overboost. Pojawia się prawidłowość $\mathrm{w}$ postaci zwiększonej liczby cząstek stałych w okolicach częściowych prędkości obrotowych z jednoczesnym ich spadkiem podczas zwiększania tej prędkości. Obciążenie w niewielkim stopniu (lub wcale) wpływa na liczbę cząstek stałych.

Wnioski te nie wyczerpują $\mathrm{w}$ pełni zagadnienia dotyczącego emisji spalin pojazdów bojowych. Kolejnym krokiem powinno być przeprowadzenie podobnych badań dla pojazdu znajdującego się w eksploatacji i przeprowadzenie analizy porównawczej uzyskanych wyników.

\section{Literatura}

[1] Directive 94/12/EC of the European Parliament and the Council of 23 March 1994: Relating to measures to be taken against air pollution by emissions from motor vehicles and Amending Directive 70/220/EEC; Commission Directive 96/44/EC of 1 July 1996 Directive 96/69/EC of 8 October 1996.

[2] Ensfield C., Bachman L.J., Erb A., Bynum C.: Evaluating real-world fuel economy on heavy duty vehicles using a portable emissions measurement system, SAE Technical Paper Series 2006-01-3543. 
The evaluation of the exhaust emission level of combat vehicles under difficult... Ocena wtaściwości ekologicznych pojazdów bojowych w warunkach poligonowych...

[3] Merkisz J., Mazurek S.: Pokładowe systemy diagnostyczne pojazdów samochodowych. Wydawnictwa Komunikacji i Łączności, Warszawa 2009.

[4] Merkisz J., Pielecha I., Pielecha J.: Gaseous and PM emission from combat vehicle engines during start and warm-up. SAE International Powertrains, Fuels and Lubricants Meeting, San Diego, SAE Technical Paper Series 201001-2283.

[5] Merkisz J., Pielecha J., Bielaczyc P.: Stan cieplny silnika spalinowego a emisja związków szkodliwych. Wydawnictwo Politechniki Poznańskiej, Poznań 2001.

[6] Merkisz J., Pielecha J.: Analysis of Particle Concentrations and Smoke in Common-Rail Diesel Engine, SAE Technical Paper Series 2008-01-1743.

[7] Merkisz J., Radzimirski S., Pielecha J.: Pragmatyczne podstawy ochrony powietrza atmosferycznego $\mathrm{w}$ transporcie drogowym. Wydawnictwo Politechniki Poznańskiej, Poznań 2009.

[8] Schwarz E., Danielson E., Bryzik W., Keelan T., Hakim N.: NATO qualification test of Detroit Diesel 8V71-TA engine at 530 BHP with advanced ceramic components. SAE Technical Paper Series 2000-01-0524.

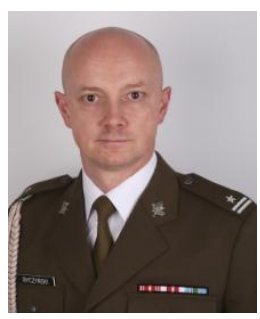

mjr dr inż. Jacek Ryczyński, Adiunkt Katedra Logistyki Wydział Zarządzania Akademia Wojsk Lądowych imienia gen. Tadeusza KOŚCIUSZKI (Udział 50\%).

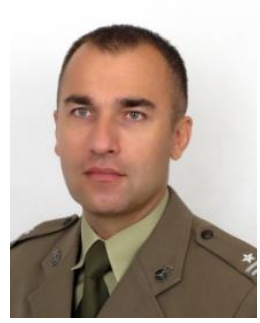

mjr dr inż. Maciej Szukalski Adiunkt Kierownik Katedry Logistyki Wydział Zarządzania Akademia Wojsk Lądowych imienia gen. Tadeusza KOŚCIUSZKI (Udział 50\%). 